\title{
Principle of Equality and Social Care Policies in the Italian Regional System between Autonomy and Centralisation
}

\author{
Giulia Maria Napolitano and Gabriella Saputelli
}

Since the Constitution of 1947, Italy has been a regional system with fifteen ordinary Regions, five special Regions (enjoying 'special forms and conditions of autonomy') and two autonomous Provinces (Trent and Bolzano) that were guaranteed legislative and administrative powers defined in the Constitution. The implementation and the evolution of Italian regionalism over the years have been strictly linked to the main political events of the Republic, which sometimes brought 'formal' revision of the Constitution (i.e. the constitutional reform of 2001) and in most cases 'substantially' affected the regional powers or the relationship between State and Regions. ${ }^{2}$

This chapter aims to analyse the extent to which the principle of equality is respected and implemented in social care policies in the Italian regional system, deepening the tensions between autonomy and centralisation arising from the relationships between State and Regions. The principle of equality is a fundamental principle of the Italian legal system, established in Article 3 of the Italian Constitution with formal (para. 1) and substantive (para. 2) meaning: 'All citizens shall have equal social dignity and shall be equal before the law, without distinction of gender, race, language, religion, political opinion, personal and social conditions. It shall be the duty of the Republic to remove those obstacles of an economic or social nature which constrain the freedom and equality of citizens, thereby impeding the

1 This chapter was produced in close cooperation of the two authors. As regards the drafting of the text, however, Dr. Napolitano edited para. 1 and 4 while Dr. Saputelli edited para. 2, 3, 5 and 6.

2 For a description of the Italian regional system and its evolution, see Stelio Mangiameli, ed., Italian Regionalism: Between Unitary Traditions and Federal Processes, Investigating Italy's Form of State (Heidelberg, Cham: Springer, 2014); Antonio D'Atena, "Regionalism in Italy," Italian Papers on Federalism, no. 1 (2013): 1. 
full development of the human person and the effective participation of all workers in the political, economic and social organisation of the country.' ${ }^{3}$ According to this second paragraph, the Republic (which means all Institutions) has the responsibility to do whatever is necessary to fulfil the principle of equality.

Article 38 of the Constitution establishes that 'Every citizen unable to work and without the necessary means of subsistence shall be entitled to welfare support. Workers shall be entitled to adequate means for their living requirements in case of accidents, illness, disability, old age and involuntary unemployment. Physically and mentally disabled persons shall be entitled to education and vocational training. Responsibilities under this Article shall be entrusted to entities and institutions established or supported by the State. Private-sector assistance may be freely provided. ${ }^{4}$

These provisions are the core of the welfare state, which has been affirmed in Europe and includes several services and benefits: pensions, healthcare, education, social care, etc.

3 On art. 3 of the Constitution see Carlo Esposito, "Eguaglianza e giustizia nell'art. 3 della Costituzione," in La Costituzione italiana, Saggi, ed. Carlo Esposito (Padova: Cedam, 1954), 17 et seq; Livio Paladin, Il principio costituzionale di eguaglianza (Milano: Giuffré, 1965); Alessandro Pizzorusso, Che cosè l'eguaglianza (Roma: Editori riuniti, 1983); Claudio Rossano, Il principio d'eguaglianza nell'ordinamento costituzionale (Milano: Giuffré, 1966); Augusto Cerri, “Uguaglianza (principio costituzionale di)," in Enciclopedia Giuridica Treccani, XIV, eds. Pasquale Stanislao Mancini and Errico Pessina (Milano: società editrice libraria, 2005), 1-13; Beniamino Caravita, Oltre l'eguaglianza formale, Un'analisidel'art. 3 comma 2 della Costituzione (Padova: Cedam, 1984); Norberto Bobbio, Eguaglianza e libertà (Torino: Giappichelli, 1995); Paolo Biscaretti di Ruffia, "Uguaglianza (principio di)," in Novissimo Digesto Italiano, XIX (Torino: Utet, 1973); Antonio Stefano Agrò, "Art. 3," in Commentario della Costituzione, ed. Giuseppe Branca (Bologna, Roma: Zanichelli, 1975), 123 et seq; AaVv., Corte costituzionale e principio di eguaglianza, Atti del Convegno in ricordo di Livio Paladin (Padova: Cedam, 2002); Alfonso Celotto, "Art. 3, $1^{\circ}$ comma," in Commentario alla Costituzione, eds. Raffaele Bifulco, Alfonso Celotto and Marco Olivetti (Milano: Utet giuridica, 2006), 65 et seq; Andrea Giorgis, "Art. 3, $2^{\circ}$ comma," in Commentario alla Costituzione, eds. Raffaele Bifulco, Alfonso Celotto and Marco Olivetti (Milano; Utet giuridica, 2006), 88 et seq.

4 On art. 38 of the Constitution see Lorenza Violini, "Art. 38," in Commentario alla Costituzione, eds. Raffaele Bifulco, Alfonso Celotto, Marco Olivetti (Milano: Utet giuridica, 20o6), 775 et seq; Ugo M. Colombo, Principi e ordinamento dell'assistenza sociale (Milano: Giuffré, 1959); Guido Corso, "I diritti sociali nella Costituzione italiana," Rivista Trimestrale di Diritto Pubblico (1981), 755 et seq; Roberto Gianolio, Luciano Guerzoni and G. Paolo Storchi, eds., Assistenza e beneficenza tra pubblico e privato (Milano: Franco Angeli, 1980); Mattia Persiani, "Art. 38," in Commentario della Costituzione, ed. Giuseppe Branca (Bologna, Roma: Zanichelli, 1979), 232 et seq; Raffaello Maggian, Il sistema integrato dell'assistenza (Roma: Carocci, 2003); Elena Ferioli, Diritti e servizi sociali nel passaggio dal welfare statale al welfare municipale (Torino: Giappichelli, 2003). 
Social care policy is one of the most discussed competences or subject matters when speaking of the fulfilment of the principle of equality and it is also emblematic of the tension between autonomy and centralisation which occurs in a regional system in the relationships between the State and the Regions. ${ }^{5}$

In the expression 'social services' are usually included 'all the activities relating to the provision and delivery of free and paid services and all monetary benefits to remove and supersede states of need and difficulty which people may encounter in the course of their lives, excluding only those provided by the pension and health care systems, and those guaranteed through the administration of justice' ${ }^{6}$

\section{The Constitutional Framework of Social Care Policy after the Constitutional Reform of 2001}

The constitutional reform of 2001 gave the Regions residual legislative powers on social care, ${ }^{7}$ while acknowledging that the State has the exclusive competence to 'determine the basic levels of care relating to civil and social entitlements to be guaranteed throughout the national territory'. ${ }^{\text {Therefore, since }}$ 2001, the Regions have become the first planning tier and the State is responsible for ensuring essential service levels and benefits in civil and social rights, delivered all over the country according to uniform standards. ${ }^{9}$

The constitutional reform was designed to introduce a high degree of regional autonomy into the Constitution and identified the essential levels of care $^{10}$ as the elements that could maintain unity and homogeneity (equality)

In the Italian system health care and education are shared competences (art. 117 para. 3 of the Constitution) while the pension system is an exclusive competence of the State (art. 117 para. 2 letter o of the Constitution).

6 Legislative Decree no. 112 of 1998, art. 128 para. 2.

$7 \quad$ Art. 117 para. 4 of the Constitution.

8 Art. 117 para. 2 letter $m$ of the Constitution. For the constitutional reform and implications of the new division of competences see Stelio Mangiameli, La riforma del regionalismo italiano (Torino: Giappichelli, 2002), 107-152; Antonio D'Atena, Diritto regionale (Torino: Giappichelli, 2017), 137-180.

9 On the Italian welfare system in an historical and sociological perspective see Yuri Kazepov, ed., La dimensione territoriale delle politiche sociali in Italia (Roma: Carocci, 2014); Cristiano Gori et al., Il welfare sociale in Italia, Realtà e prospettive (Roma: Carocci, 2015); Ilaria Madama, Le politiche di assistenza sociale (Bologna: Il Mulino, 2010).

10 On this concept see Enzo Balboni, "I livelli essenziali e i procedimenti per la loro determinazione," Le Regioni, no. 6 (2013):1183-1199; Enzo Balboni, "Coesione sociale e livelli essenziali delle prestazioni: due paradigmi paralleli della tutela multilivello dei diritti sociali," in La tutela multilivello dei diritti sociali, ed. Enzo Balboni (Napoli: Jovene, 2008); Claudio 
throughout the whole of the national territory.11 These levels constitute an inviolable set of core services which must be guaranteed by the Regions by complying with standards defined as 'essential,', ${ }^{12}$ and are protected by the Constitution by giving the State exclusive control over this subject-matter: the Regions do not have the power to reduce these levels and, if anything, they may only extend them. ${ }^{13}$

Closely related to the loss of planning powers, the State has lost the right to place allocation constraints on funding, which, however, continue to take the form of transfers from the centre to the periphery. Welfare, in fact, has hitherto been funded by a variety of different national, regional and local funds, sometimes with a part of the cost being charged to the beneficiaries in the form of co-payment. ${ }^{14}$ The main source of funding is the National Social Policies Fund, first introduced in 1997 and modified over time. Where the reform of Title V

Panzera, "I livelli essenziali delle prestazioni concernenti i diritti sociali," in Diritto costituzionale e diritto amministrativo: un confronto giurisprudenziale, eds. Giuseppe Campanelli, Michele Carducci, Nicola Grasso and Vincenzo Tondi della Mura (Torino: Giappichelli, 2010), 57-105; Michele Belletti, "I livelli essenziali delle prestazioni concernenti i diritti civili e sociali alla prova della giurisprudenza costituzionale, Alla ricerca del parametro plausibile," Le istituzioni del federalismo, no. 3-4 (2003): 613-646; Giovanni Guiglia, I livelli essenziali delle prestazioni sociali alla luce della recente giurisprudenza costituzionale e dell'evoluzione interpretativa (Padova: Cedam, 2007); Anna Banchero, "I livelli essenziali delle prestazioni nell'ambito dei servizi alla persona: dalla tutela della salute alla protezione sociale," Quaderni regionali, no. 2 (2008): 461-483; Lara Trucco, "Livelli essenziali delle prestazioni e sostenibilità finanziaria dei diritti sociali," Gruppo di Pisa, Rivista, no. 3 (2012): 1-92, https://www.gruppodipisa.it/images/rivista/pdf/Lara_Trucco_-_Livelli_ essenziali_delle_prestazioni_e_sostenibilita_finanziaria_dei_diritti_sociali.pdf; Cristiano Gori, "I livelli essenziali di assistenza," in La riforma dei servizi sociali in Italia, L'attuazione della legge 328 e le sfide future, ed. Cristiano Gori (Roma: Carocci, 2002), 55 et seq.

11 According to Luisa Torchia, "Premessa," in Welfare e federalismo (Bologna: Il Mulino, 2005), 15, in the Italian system the clause concerning essential levels of care could be the keystone of the relationship between welfare and federalism, and serve as a basis for the construction of a unitary system in which responsibilities between different levels of government are consistently distributed.

12 Enzo Balboni, "Il concetto di 'livelli essenziali e uniformi' come garanzia in materia di diritti sociali," Le istituzioni del federalismo, no 6 (2001): 1103 et seq.

13 Judgements no. 10 and 207 of 2010; no. 200 and no. 322 of 2009; no. 387 of 2007; no. 248 of 2006.

14 The Constitutional Court (in Judgement no. 423 of 2004, point 4.2.) indicated the major novelties introduced by Act no. 328 'setting forth a general rule according to which the implementation of an integrated system of welfare services is provided for from a variety of different funding sources to which the Central Government, the Regions and the Local authorities contribute according to their respective powers'. 
redefined the procedures for financing the Regions, ${ }^{15}$ it removed the allocation constraint on funds from the National Social Fund thus allowing the Regions to manage their social policies autonomously, using transfers.

At the legislative level, just one year before the constitutional reform of 2001, the State adopted framework Act no. 328 of $2000,{ }^{16}$ which formally is no longer binding on the Regions but still 'authoritative', because all the regional re-organisation laws that followed took up many of its innovations (such as the model of an integrated network system, the central role of the municipalities as the essential link in the care system, the 'zonal plan' as the programming instrument, and the enhanced role given to the 'third sector'). The emerging system of regional legislation was not dissimilar to that of the framework Act, except for one major difference, in that the regional Governments achieved planning powers and general legislative powers over welfare services, even if this legislative power was bound to run into the State's legislative power to establish essential levels of service.

In general, placing social care services among the residual competences of the Regions has substantially increased the volume of legislation and regulations governing this sector, and has greatly increased the caseload of litigation between the State and the Regions before the constitutional Court on matters of competence. ${ }^{17}$ Moreover, the new financing model, whose profile was not

15 For the financial model see Luca Antonini, "La vicenda e la prospettiva dell'autonomia finanziaria regionale: dal vecchio al nuovo art. 119," Le Regioni (2003): 34 et seq; Piero Giarda, "Le regole del federalismo fiscale nell'articolo 119: un'economista di fronte alla nuova Costituzione," Le Regioni (2001): 1425 et seq; Davide De Grazia, "Lautonomia finanziaria degli enti territoriali nel nuovo Titolo V della Costituzione," Le istituzioni del federalismo, no.2 (2002): 267 et seq; Stelio Mangiameli, "Autonomia finanziaria," in Dizionario sistematico di Diritto costituzionale, ed. Stelio Mangiameli (Milano: Il sole 24 Ore, 2008); Enrico Buglione, "Regional Finance in Italy: Past and Future," in Italian Regionalism: Between Unitary Traditions and Federal Processes, Investigating Italy's Form of State, ed. Stelio Mangiameli (Heidelberg, Cham: Springer, 2014), 307 et seq.

16 For comments see Enzo Balboni, Bassano Baroni and Angelo Mattioni, eds., Il sistema integrato dei servizi sociali, Commento alla legge no. 328 del 2000 e ai provvedimenti attuativi dopo la riforma del titolo V della Costituzione (Milano: Giuffré, 2003).

17 The role of the constitutional Court has been fundamental in defining the division of competences between the State and the Regions. According to Stelio Mangiameli, "Il Titolo V della Costituzione alla luce della giurisprudenza costituzionale e delle prospettive di riforma," Rivista AIC, no. 2 (2016), 36, https://www.rivistaaic.it/it/rivista/ultimicontributi-pubblicati/stelio-mangiameli/il-titolo-v-della-costituzione-alla-luce-dellagiurisprudenza-costituzionale-e-delle-prospettive-di-riforma: 'the constitutional case law was animated by the desire to safeguard the unity of the legal system, supporting even in a substitute role - the state legislature, and what has been done has had the sense to maintain an overall balance'. On this role see also Antonio D'Atena, Tra autonomia e 
clearly defined and which was difficult to establish at the time, was one of the critical aspects of the system from the outset. This inevitably led to a great deal of litigation before the constitutional Court, which was called upon to rule on a complex range of issues.

Both tiers of government have been trying to carve out a place for themselves in the new system: the Central Government has been endeavouring to hold on to its existing prerogatives, while the Regions have been determined to defend the powers already acquired, as well as their autonomy.

\section{What the State Has (Not) Done in the Field}

Unlike healthcare ${ }^{18}$ and education, ${ }^{19}$ the State has failed to lay down the essential levels of welfare during the ten years following the constitutional reform. This legal vacuum is of particular importance because of what is involved is the policy financing, as well as what is deemed to be (or rather, what the Central Government considers to be) the unchangeable core of services and benefits that must be guaranteed in order to enable citizens to fully enjoy their civil and social rights. The main reasons for the persistence of this state of affairs are that the definition of the essential level of care implies that the State is to provide the relevant funding.

The 2003 Budget Act ${ }^{20}$ entrusted the task of defining the essential levels of welfare to a Decree of the President of the Council of Ministers in agreement

neocentralismo, Verso una nuova stagione del regionalismo italiano? (Torino: Giappichelli, 2016), chapters III and IV.

18 The Decree of the President of the Republic of 29 November 2001 defined the essential levels of health care; see George France, "The Italian Health Care System and the Economics of the Right to Health," in Italian Regionalism: Between Unitary Traditions and Federal Processes, Investigating Italy's Form of State, ed. Stelio Mangiameli (Heidelberg, Cham: Springer, 2014), 335 et seq. Essential levels of health care have recently been updated by a prime ministerial decree (d.P.C.m.) of 12 January 2017.

19 Actually, there are no clear indications regarding the essential standards to be met with regard to education except for a reference in Article 21 of Act no. 59 of 1997 which provided for 'unitary and nationwide levels of the right to an education, and the elements common to the whole State school system regarding Central Government management and planning'. Subsequently, Act no. 53 of 2003 gave the government delegated powers to lay down general rules for education and set the essential levels of the services to be provided by schools and vocational training. Legislative Decree no. 226 of 2005 then laid down the essential levels for the second cycle of the educational and vocational training system.

Act No. 289 of 2002, Article 46 (3). 
with the State-Regions Conference (or the Joint Conference), with the limitation of the resources available in the National Social Fund. However, this procedure has never been applied. Later attempts were made by a number of institutional players to provide a standard nationwide definition of essential levels of care, but this never went further than being a mere proposal. The deadlock was not resolved, and between 2004 and 2005 the Ministry of Labour and Social Policies drafted a document defining a list of services and benefits, with an explicit acknowledgement of the work done by the Regional Governments and of the inertia of Central Government. ${ }^{21}$

Over the years, several acts have indicated how to define and finance the essential levels of care without indicating the contents, which nowadays remain those of the framework Act 328 of $2000^{22}$ - even if the Court has considered the levels defined in that Act to be 'a series of services and benefits that are wholly heterogeneous both in terms of content and conditions of entitlement.'. 23

The results of this failure are the disaggregation of benefits, the lack of a commonly agreed list ${ }^{24}$ and of a joint commonly agreed approach to the nonmonetary benefits and services to be provided to people in a specific state of need. ${ }^{25}$ The main consequence of the absence of State intervention on the

21 As stated in the Social Services Monitoring Report, published by the Directorate-General for the Management of the National Fund for Social Policies and of Social Expenditure at the Ministry of Labour and Social Policies, ' $t \mathrm{t}]$ he Regions are beginning to govern types of services and benefits that have been traditionally the preserve of Central Government, such as poverty-alleviation measures, legislation on matters very closely connected with the (as-yet undefined) 'essential levels of care"; Directorate-General for the Management of the National Fund for Social Policies and of Social Expenditure at the Ministry of Labour and Social Policies, Social Services Monitoring Report (September 2005), 44.

22 The law seemed to point the way to establishing 'the essential levels of welfare to be delivered in the form of goods and services in accordance with the characteristics and requirements established in national, regional and zonal plans, within the limits of the resources of the National Fund for Social Policies, taking into account the ordinary resources already allocated by the local authorities for social expenditure' (Article 22).

23 Judgement no. 224 of 2006.

24 It was not until October 2009 that a 'Nomenclature of services and social measures' was adopted by the Conference of Regions and of Autonomous Provinces. This idea was first broached at the beginning of 2006 following an analysis of the results of the 'Survey of social services and measures' adopted by individual and associated municipalities, conducted by ISTAT in conjunction with the Ministry of Labour, Health and Social Policies, the General Accounting Office and the regional Governments. The nomenclature can be found on http://www.regioni.it/upload/DOCCRP10\%29NOMENCLATORE_SERVIZI_ SOCIALI.pdf.

25 Cristiano Gori, "Applicare i livelli essenziali nel sociale," Prospettive sociali e sanitarie 33, no. 15 (2003): 1 et seq; Cristiano Gori and Ilaria Madama, "Le politiche socio-assistenziali," 
essential levels of care means that not everyone has access to the same level of care across the country.

The only two provisions which have been introduced in terms of essential levels of care during the past fifteen years are the $\operatorname{ISEE}^{26}$ and the recent Inclusion Income Act. ${ }^{27}$ The latter is the means by which the State ensures uniformity in care delivery across the country, thus overcoming the absence or different degrees of income support.

From a financial point of view, even in the years that followed the constitutional reform, measures were taken to maintain pre-existing funds. ${ }^{28}$ Additional sectoral funds, parallel to the National Fund, were also created, such as the Family Policies Fund, ${ }^{29}$ the Youth Policies Fund, ${ }^{30}$ the Fund for the Non-Self-Sufficient, ${ }^{31}$ all of which were designed to support interventions in the social sphere. Some of these funds, mostly set up under the State's Budget Acts, have led to numerous legal disputes with the State. In particular, the Regions claimed their right to new money transfers from the Central Government with no allocation constraints, and they accused the State of having created funds for matters falling within the Regions' competence in violation of their constitutional autonomy over revenue and expenditure (Article 119 of the Constitution).

in La riforma del Welfare, Dieci anni dopo la 'Commissione Onofri', ed. Luciano Gurzoni (Bologna: Il Mulino, 2007), 347-358; Alberto Comino, Alessandra De Marco and Alessandro Natalini, "La determinazione dei livelli essenziali delle prestazioni," in Welfare e federalismo, ed. Luisa Torchia (Bologna: Il Mulino, 2005), 95 et seq.

26 Legislative Decree no. 109/1998, amended in 2011 and 2013. ISEE is the index for evaluating the economic situation of the family in order to access social services or to establish the co-payment of social benefits. It was introduced by Legislative Decree no. 109/1998, and then amended by Article 5 of Legislative Decree 201/2011 (converted into Act no. 214/2011) and by d.P.C.m. no. 159/2013, Regolamento concernente la revisione delle modalità di determinazione e i campi di applicazione dell'Indicatore della Situazione Economica Equivalente (ISEE), which established that it has to be considered an essential level of care, thus binding for the Regions.

27 Act no. 33/2017 was adopted by the State to combat poverty and social exclusion and introduced the so-called 'Reddito di Inclusione' (Inclusion Income), a measure that provides a form of direct income for households below the absolute poverty line and is aimed at ensuring economic autonomy and occupation for idle, unemployed or precariously employed citizens.

28 In addition to those listed below there is also the National Fund for Children and Adolescents instituted by Act no. 285 of 1997 .

29 Instituted by Decree-Act no. 223 of 2006 , enacted by Act no. 248 of 2006 .

$30 \quad$ Instituted by Decree-Act no. 223 of 2006, enacted by Act no. 248 of 2006 .

31 Instituted by Act no. 296 of 2006 (the 2007 Budget Act). 


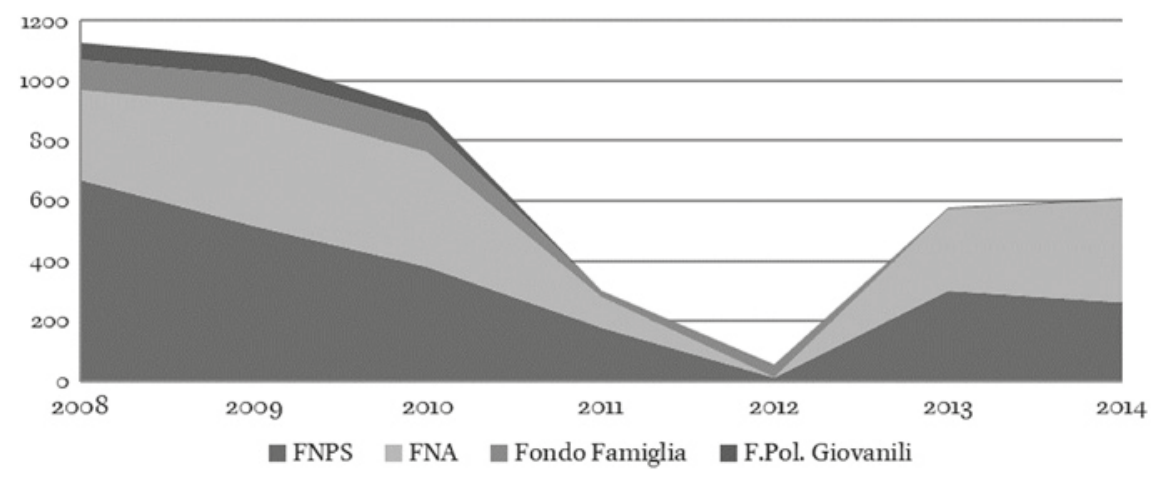

FIGURE 10.1 National funds for social policies: share allocated to Regions

For instance, during the economic crisis of the late 200os, the State drastically reduced the shares of the National Social Fund allocated to the Regions (see Figure 10.1) and adopted a different measure instead: the Social Card, ${ }^{32}$ which cannot be considered an essential level of care but can be regarded as a way of aiding the satisfaction of basic needs (such as for purchasing food, paying for gas bills and healthcare services, etc.).

The Act which introduced the Social Card was challenged by the Regions on the grounds that it infringed their competence over social care matters. However, the constitutional Court saved the provisions, because 'State laws designed to protect particularly disadvantaged individuals, although encroaching on the Regions' competence in the field of social services and assistance, must be evaluated also in the light of the fundamental principles of Articles 2 and 3, para. 2, 38 and Article 117, para. 2 letter M'. In consequence, the principles of equality and solidarity represent the foundation for State intervention, which is permitted in extraordinary, exceptional and urgent cases resulting from international economic and financial crisis situations such as those that affected the country in 2008 and 2009. Moreover, according to the reasoning followed by the Court, the jurisdiction of the State and the exceptional situation in which it was exercised also make the requirement to respect the principle of loyal cooperation irrelevant, but rather involve the

32 D.L. 112/2008, converted into Act no. 133 of 2008 (Conversion into law, with amendments, of Law Decree no 112 of 25 June 2008 laying down urgent provisions for economic development, for the simplification, competitiveness and stabilisation of public finance and tax equality), amended by Article 6o of D.L. no. 5/2013. 
exercise of the regulatory power by the State, and the establishment of the discipline in detail. ${ }^{33}$

In this judgement, the Court clearly considered the State to be the main guarantor of the principle of equality, and despite the division of competences between the State and the Regions, it justified the intervention of the State on the basis of the constitutional framework.

Finally, it is worth specifying that even the act carrying out fiscal federalism - adopted with considerable delay and whose unwieldy process of implementation was interrupted because of the negative economic cycle caused by the international economic crisis - requires essential levels of care to be defined because it lays down new rules for financing these services. ${ }^{34}$

\section{What the Regions Have Done: Regional Social Care Policies as 'Labs' for Welfare Policies and as a Test-Bench for Autonomy}

The national framework law and the reform of Title $\mathrm{V}$ of the Constitution fostered the development of different regional welfare models. All Regions issued welfare laws which fall into three groups: (1) those issued before the framework Act No. 328 of $2000,(2)$ those passed more or less at the same time as the framework law, and (3) those enacted subsequently. ${ }^{35}$ Despite their different procedures, planning in all Regions takes place at two levels: at the regional

33 Constitutional Court, Judgement n. 10 of 2010, point 6.4; Judgement no. 62 of 2013. For comments on the judgements: Adele Anzon Demmig, "Potestà legislativa regionale residuale e livelli essenziali delle prestazioni," Giurisprudenza Costituzionale, no. 1 (2010): 155 et seq; Erik Longo, "I diritti sociali al tempo della crisi, La Consulta salva la social card e ne ricava un nuovo titolo di competenza statale," Giurisprudenza costituzionale 55 (2010): 164 et seq; Marta Cerioni, "Un'ulteriore fattispecie di superamento giurisprudenziale della rigidità del riparto di competenze: 'I livelli essenziali delle prestazioni al tempo della crisi', Giurisprudenza italiana (2010): 2518 et seq; Antonio Ruggeri, “'Livelli essenziali' delle prestazioni relative ai diritti e ridefinizione delle sfere di competenza di Stato e Regioni in situazioni di emergenza economica (a prima lettura di Corte cost. n. 10 del 2010)," forumcostituzionale.it (February 2010), http://www.forumcostituzionale. it/wordpress/images/stories/pdf/documenti_forum/giurisprudenza/2010/0002_nota_10_ 2010_ruggeri.pdf; Claudio Panzera, "I livelli essenziali delle prestazioni fra sussidiarietà e collaborazione," Le Regioni, no. 4 (2010): 941.

34 Act no. 42 of 2009.

35 On the regional welfare models see Giulia Maria Napolitano, "Social Care as a Workshop for Regional Welfare Policies," in Italian Regionalism: Between Unitary Traditions and Federal Processes, Investigating Italy's Form of State, ed. Stelio Mangiameli (Heidelberg, Cham: Springer, 2014), 36o-362. 


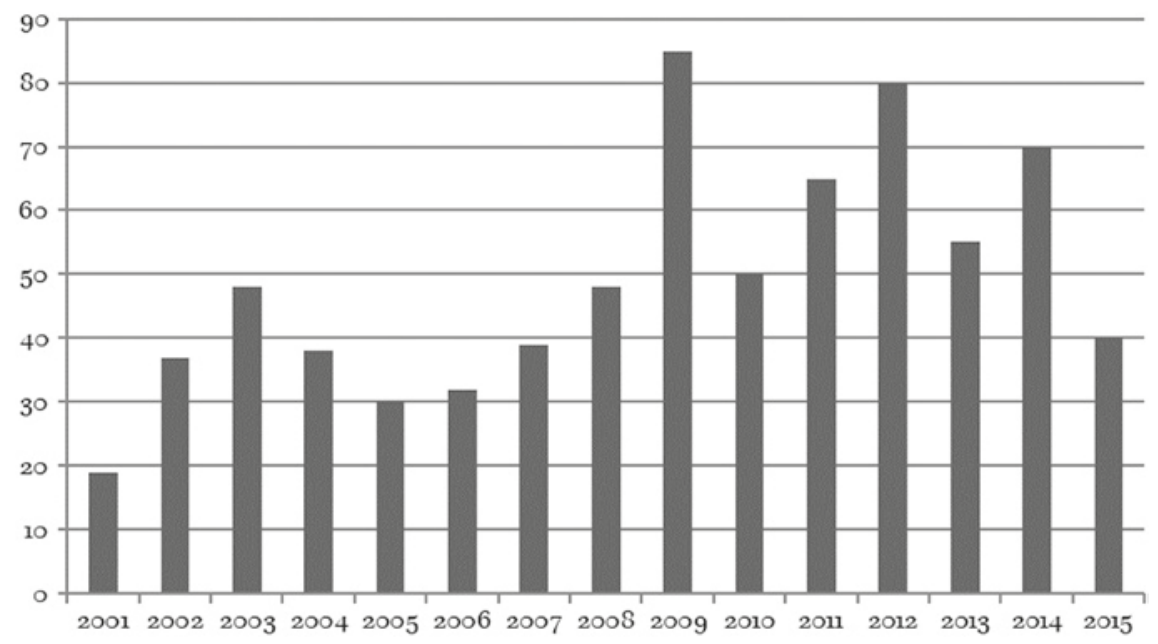

FIGURE 10.2 Regional legislation on social care

level, through the Welfare Plan or the Social and Health Care Plan, and at the sub-regional level, through the Zonal Plan.

A total of 739 laws on welfare and health care policies were issued between 2001 and 2015 , accounting for about $8 \%$ of the total regional legislation produced in that period. ${ }^{36}$ The number of laws varied from one year to another during these fifteen years (see Figure 10.2). The figures reveal the regional lawmakers' increasing interest in, and sensitivity towards, social policies.

Within social and health care policies there are four areas that account for the bulk of the laws passed in the 2001-2015 period (see Figure 10.3) ) $^{37}$ the 'third sector' and the reorganisation of care and charitable entities (16\%), family and mother-child policies (16\%), disabilities and invalidity (15\%) and organisational-institutional matters, namely implementation and management of the system (11\%).

The lack of indications on services and benefits, as well as on the minimum levels of care to be guaranteed, together with the large number of regional

36 ISSIRFA sources; see the systematic collection of regional legislation in the chapters edited by Giulia Maria Napolitano and published annually in "Tendenze e problemi della legislazione regionale," in Rapporto sulla legislazione tra Stato, Regioni e Unione europea, ed. Camera dei deputi (Rome: Camera dei deputati, 2007-2015), http://www.issirfa.cnr.it/ rapporto-camera.html.

37 Napolitano, "Tendenze e problemi." 


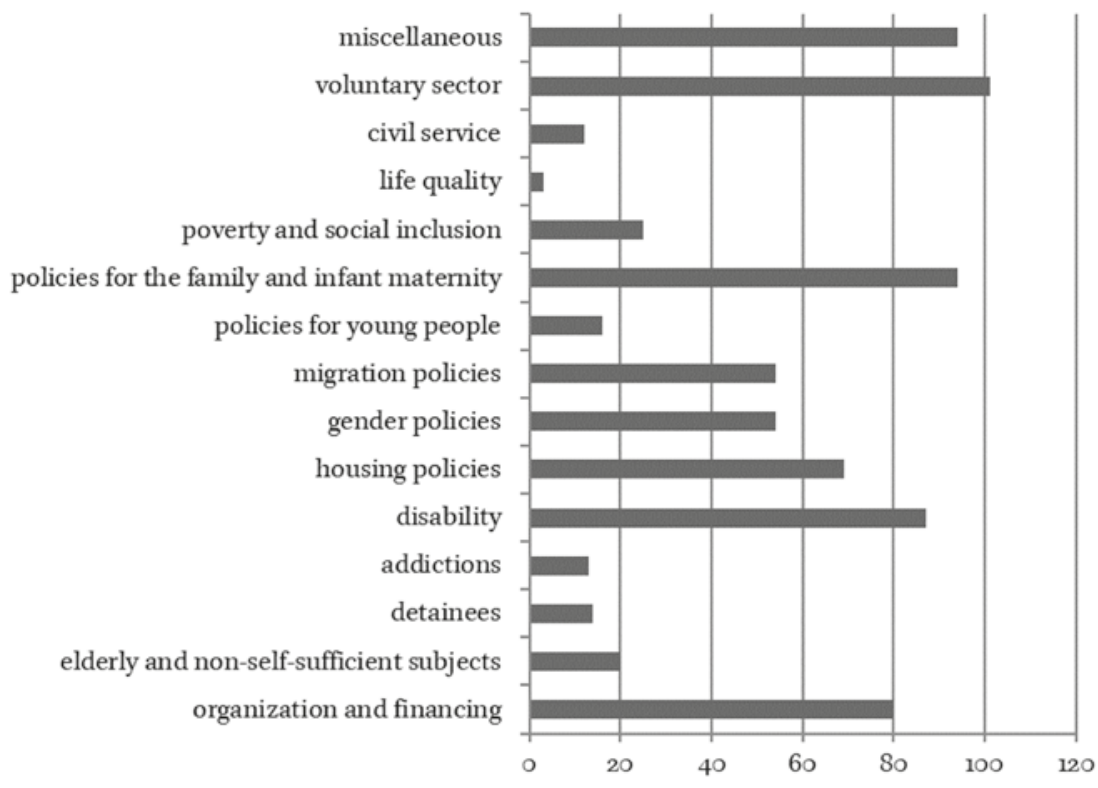

FIGURE 10.3 Regional legislation governing welfare and health care: distribution per sector

legislation and administrative measures on social and welfare policies, also free from State funding and planning constraints, have given rise to different approaches to the question of essential levels of care by the Regions. They intervened in this process in three ways, which may be summarised as pragmatic, wait-and-see, and innovative. In the first approach, some Regions have not addressed the issue of qualifying services and benefits as 'essential' but have set objectives and priorities on the basis of available resources. Others the 'wait-and-see' Regions - have wholly or partially transposed the text of the State law into regional law, or simply make reference to the articles of the State law without issuing provisions defining what those essential levels are. Lastly, the innovative Regions have moved far beyond the State law provisions in that they have broadened the range of services and benefits. In all these cases, it could be said that the Regions have somehow filled the empty space left by the State in defining the essential levels of services.

In the absence of State regulations on the essential levels of care, regional policy choices were strongly differentiated throughout the country. Subsequently, since the essential levels of care were never defined, all the benefits and services provided by the Regions in the social sphere were mapped in the 'Interregional Nomenclature of services and social measures' 
drawn up by the Social Policies Committee of the Conference of Regions and of the Autonomous Provinces. This document was adopted in 2009 by the Conference of Regions and of Autonomous Provinces and updated in 2014 both in terminology and content. The Nomenclature has provided a grouping of social services and defined macro levels of services, within which 'service objectives' have been identified.

With the economic crisis, the Regions have expanded existing services or introduced new measures to support incomes (examples: baby/child bonus, income support measures, etc.). These measures vary depending on the financial resources available for each Region, thus increasing the gap between Regions (especially between North and South), and on political pressure.

From a financial point of view, the Regions and the Municipalities have contributed with their own resources, ${ }^{38}$ besides receiving transfers from the State and EU funds, with co-payment by beneficiaries which vary from one Region to another. On the whole, during the economic crisis, regional resources have been increased while national resources have been reduced. Therefore, it may be stated that the Regions have provided social safety nets during the economic crisis thus filling in the vacuum left by the State. This aspect was adversely affected by the local governments' failure to achieve financial autonomy, which meant that the regional policies were managed through a top-down approach to the detriment of the accountability and autonomy of local governments. This situation was considerably worsened over the years because public spending was curtailed, and the coordination of public finance led to an impoverishment of the already scanty regional resources. ${ }^{39}$

$3^{8}$ Regional resources take the form of co-financing that is added to Central Government transfers for the management and maintenance of the care system, and to other funds to finance policies identified by the Regions as priorities, such as the Regional Funds for the Non-Self-Sufficient, or to provide various kinds of support for family policies and policies for immigrants.

39 On the impact of the coordination of public finance over regional policies see D'Atena, Diritto regionale, 220; Michele Belletti, "Forme di coordinamento della finanza pubblica e incidenza sulle competenze regionali, Il coordinamento per principi, di dettaglio e 'virtuoso', ovvero nuove declinazioni dell'unità economica e dell'unità giuridica," in Il regionalismo italiano tra giurisprudenza costituzionale e involuzioni legislative dopo la revisione del Titolo V-Atti del Seminario, ed. Stelio Mangiameli (Milano: Giuffré, 2014), 86 et seq; Guido Rivosecchi, "Il coordinamento della finanza pubblica: dall'attuazione del titolo V alla deroga al riparto costituzionale delle competenze," in Il regionalismo italiano tra giurisprudenza costituzionale e involuzioni legislative dopo la revisione del Titolo V-Atti del Seminario, ed. Stelio Mangiameli (Milano: Giuffré, 2014), 147 et seq; on the impact of crisis over regionalism and the relationship between State and Regions see Stelio Mangiameli, Le Regioni italiane tra crisi globale e neocentralismo (Milano: Giuffré, 2013). 
The Regions have also been laboratories for testing policies addressing new needs, such as in the field of immigration: the Regions were the first institutions to develop measures to deal with this situation, in some cases including, and in other cases excluding, migrants from services, and causing State intervention in both cases. ${ }^{40}$

In fact, even if the State has exclusive competence over immigration matters, ${ }^{41}$ specifically migration flows, the Regions have claimed the power to guarantee the integration of immigrant populations in different ways and with different means, recognising their entitlement to essential health and welfare services and benefits regardless of whether their presence in the territory is legal or not. All the comprehensive laws on immigration, except for the regional law of Lazio, have been challenged before the constitutional Court ${ }^{42}$ by the State.

The Constitutional Court as a Balance between the State and the Regions, between Equality and Autonomy

The constitutional Court has been called upon to strike a balance between State and Regional competences. The case law of the last fifteen years shows that the Court has taken on the role of mediator between autonomy and equality.

40 On this issue see Laura Ronchetti, ed., I diritti di cittadinanza dei migranti, Il ruolo delle Regioni (Milano: Giuffré, 2012); Laura Ronchetti, ed., La Repubblica e le migrazioni (Milano: Giuffré, 2014).

41 Article $117(2)$ (b) of the Constitution provides that immigration is one of the subjectmatters over which the State has exclusive competence.

42 The main complaint made against them is that Regions have unlawfully encroached on the State's powers in the matter of immigration and unlawfully recognised 'the rights of immigrants living illegally in Italy or awaiting regularization' (Referral against the Campania Region, No. 62 of 2010, published in the Gazzetta Ufficiale, no. 20 (May, 2010). According to a ruling of the Constitutional Court, "[t]he Regions are fully empowered to enact legislation relating to immigration [...] it being understood that this legislative power may not be applied to matters referring to policies for planning the entry or stay of immigrants on national soil, but over other matters, such as the right to study and to receive social care, which fall within the scope of the Regions' concurrent or residual powers' (Judgements nos. 134 and 299 of 2010, italics added). The Constitutional Court recently reiterated the fact that 'public intervention relating to foreign nationals cannot be limited merely to controlling the entry and stay in Italy of immigrants, but must necessarily consider other areas - welfare, education, healthcare, housing - which involve many legislative powers, some of which are vested in the State and others in the Regions' (Judgement no. 61 of 2011, see also Judgements no. 300 of 2005; no. 156 of 2006), a fortiori because 'foreign nationals possess all the constitutionally guaranteed basic personal rights' (Judgement no. 148 of 2008, see also Judgement no. 432 of 2005; no. 324 of 2006). 
On the one hand, the constitutional Court has recognised social care as a residual competence of the Regions because it is not on the list of exclusive competences of the State nor is it included among the concurrent competences. ${ }^{43}$ On the other hand, the constitutional Court has explicitly recognised that the State's competence to establish essential levels of services regarding civil and social rights is not a 'subject-matter' strictu sensu, but a 'competence of Central Government that may affect all subject-matters in respect of which the State legislator must lay down the necessary rules to guarantee that everyone, throughout the country, may enjoy guaranteed services, as the essential substance of these rights, without Regional law being able to restrict or condition them. ${ }^{4}$

The cross-cutting nature of State competence entails 'a strong impact on the exercise of the legislative and administrative powers of the Regions, ${ }^{45}$ so that its exercise requires compliance with the principle of loyal cooperation between the State and the Regions, ${ }^{46}$ unless there are exceptional circumstances in which the determination of the essential levels of care is not sufficient to effectively realize the purpose $[\ldots]$ of protecting extremely disadvantaged individuals' but it legitimises the State to provide welfare benefits directly, without considering the principle of loyal cooperation with the Regions. ${ }^{47}$

For these reasons, the State, in the few cases in which it has determined the essential levels of health care or social care, has often provided instruments for the involvement of the Regions (in the form of 'agreement') to respect their competences. In the case of the ISEE, for instance, the determination of the index, of the types of benefits provided, and of the income level providing access to the benefits significantly affects the residual competence of the Regions in the field of 'social services' and, at least potentially, the finances of the Region that sustain the economic burden of such services. According to the Court, "[it] is, therefore, evident that such determination of the ISEE requires the reconsideration of local situations and the assessment of financial sustainability [...] It follows that fair cooperation by the Region is necessary to implement the challenged provision':48

43 Cfr., ex plurimis, Judgements no. 296 of 2012; no. 61 of 2011; no. 121 and no. 10 of 2010; no. 168 , no. 166 and no. 5 o of 2008 ; no. 300 of 2005 .

Judgement no. 282 of 2002. See also Judgements no. 203 of 2012; no. 232 of 2011; no. 10 of 2010; no. 322 of 2009; no. 168 and no. 5 o of 2008; no. 162 and no. 94 of 2007; no. 282 of 2002. On the characteristics of cross-cutting matters see D'Atena, Diritto regionale, 161 et seq.

45 Judgements no. 8 of 2011 ; no. 88 of 2003.

46 Judgements no. 330 and no. 8 of 2011; no. 309 and no. 121 of 2010; no. 322 and no. 124 of 2009; no. 162 of 2007; no. 134 of 2006; no. 88 of 2003 .

47 Judgement no. 10 of 2010 on the 'Social card'.

48 Judgement no. 297 of 2012. 
An important part of the case law of the Court concerns the financial system. Both the National Social Fund and the 'parallel funds' established after 2001 for social and health care purposes have been challenged before the constitutional Court. The circumstances surrounding these funds are emblematic of the huge efforts that the Court has deployed to resolve the issues created by the Central Government's attempts to continue laying down social policies in respect of matters that the Regions are empowered to manage autonomously. In particular, the Court has declared a number of State funds to be unconstitutional, ${ }^{49}$ on the grounds that 'funding with allocation constraints shall not be provided for matters and functions of Regional competence, whether they fall within the exclusive competence of the Regions or within their concurrent powers, albeit in compliance with the fundamental principles established in State law' ${ }^{50}$ However, the Court has also ruled that any effects they had already produced should be retained, on the grounds that 'the social nature of the benefits provided, which refer to fundamental rights, are such that the continuity of said services are to be guaranteed, on the basis of principles of social solidarity, such that it is necessary to maintain any expenditure proceedings in progress, even if they have not yet been completed. 51

On the other hand, the Court has 'saved' other Central Government funds, ${ }^{52}$ sometimes on the grounds that the provisions were unable to undermine regional powers, ${ }^{53}$ or acknowledging the unitary and indivisible nature of the

49 In Judgement no. $5^{\circ}$ of 2008, the Court ruled the Fund for the Social Inclusion of Immigrants (article 1 (1267) of Act no. 296 of 2006), and the Fund for the Removal of Architectural Barriers (article 1 (389) of Act no. 296 of 2006) to be unconstitutional. In Judgement no. 370 of 2003 it also ruled that the Fund for the Institution of Nurseries (article 70 of Act no. 448 of 2001) was unconstitutional. The Court has not only intervened in relation to 'parallel' funds but also in relation to the National Social Fund itself, and has reiterated the ruling that any allocation constraint is non-legitimate, even if it relates to only a portion of the Fund, because this would limit the autonomy of the Regions (Judgement no. 423 of 2004). In reality, the Court has challenged the very survival of the Fund once the constitutional reform is implemented, since the structure and function of the Fund do not reflect any of the financing instruments provided for by the new article 119 of the Constitution. At the same time, continuing to keep its balance, the Court has not wholly excluded the survival of the Fund once article 119 is implemented, provided that it is used exclusively to finance welfare or minimum levels of care, which are exclusive competences of the State (see Judgement no. 423 of 2004).

$5^{\circ}$ Judgement no. 160 of 2005. See also Judgements no. $5^{\circ}$ of 2008; no. 77 and 51 of 2005; no. 423 and 16 of 2004 ; no. 370 of 2003 .

51 Judgement no. 50 of 2008. See also Judgements no. 423 of 2004; no. 370 of 2003 .

$5^{2}$ Judgements no. 453 of 2007; no. 141 of 2007. For example, the Family Policies Fund, the Youth Policies Fund, the Equal Rights and Opportunities Policies Fund. Italics added. 
Fund and its purpose of being used for matters over which both Regions and State have competence, ${ }^{54}$ without any material sphere being identifiable as having prevalence over the others. In this case, referring to the principle of loyal cooperation, the Court ruled that the agreement or the opinion issued by the Joint Conference was an instrument for 'safeguarding' the fund.

During the years of the crisis, the Court was called upon on several occasions to judge the curtailing of regional resources imposed in order to ensure budgetary consolidation. In the abundant case law on the coordination of public finance, it is worth mentioning the judgement stating that 'the determination by the State of the essential levels of service with regard to civil and social rights that are to be ensured across the national territory is useful. With regard to the health sector this determination occurred recently with d.P.C.m. of 12 January 2017 (prime ministerial decree) which offers the Regions a significant orientation criterion for identifying objectives and areas where resources are to be reduced, also indicating the threshold below which spending - provided it is efficient - cannot be further compressed (Judgement no. 65 of 2016). ${ }^{55}$ Failure to set essential levels for social policies has led to a reversal in the burden of proof, ${ }^{56}$ and so the Regions, in order to counter the linear cuts made within the framework of a policy curbing public spending, are compelled to provide evidence showing that it is impossible for them to offer adequate levels of service to cater to the needs of the people. ${ }^{57}$

The efforts made over the past few years by the constitutional Court seem to have been designed with several purposes: firstly, to reconcile the need to guarantee adequate economic support for social policies, with respect for the autonomy of the Regions in the management of social policies; secondly, to restrict attempts by the Executive to assert its earlier overarching Central Government power; thirdly, to ensure that any effects produced by the allocation of resources are protected, while ensuring that any possible benefits, rights or expectations created are not cancelled; lastly, to shuttle the welfare model into the new system via a transition phase. This complex operation shows the Court to be walking the tightrope in an area where the boundaries are still ill-defined while awaiting the implementation of the constitutional reform that the Court itself has so frequently called for.

\footnotetext{
54 This particular case referred to the Family Policies Fund and to the National Fund against Sexual Violence (Judgement no. 453 of 2008).

55 Judgement no. 154 of 2017 , point 4.6.2.1.

56 Judgement no. 154 of 2017.

57 Judgements no. 65 and 141 of 2016.
} 
Finally, it is necessary to mention the case law on migration, because for the constitutional Court the protection of equality also extends to the recognition of social assistance benefits to foreigners present in the country. ${ }^{58}$ For instance, in Judgement 40/2011, the Court declares unconstitutional an Act of the Region of Friuli Venezia Giulia which offers access to the integrated system of social services of the Region only to EU citizens who have resided in the Region for at least thirty-six months. The exclusion of entire categories of persons was considered by the Court to be a violation of the principle of equality, since it introduces arbitrary distinctive elements that constitute the prerequisite for provisions which, by their very nature, do not tolerate distinctions based on citizenship, or on particular types of residence. ${ }^{59}$

\section{Concluding Remarks: The Relationship between the State and the Regions, from Conflict to 'Political Agreement' and Institutional Involvement}

The State has frequently claimed the power to define the essential levels of care, but it has been unable to do so, even by resorting to instruments other than State law. The Regions have shown their determination to protect their powers by claiming, on the one hand, compliance with the principle of legality, and on the other, they have defended their right to play a part, in one way or another, in defining social policies based on the principle of loyal cooperation.

As pointed out, the Regions have filled the vacuum left by the State in defining the essential levels of services and the State has intervened in very few cases to guarantee equality. However, this role of the Regions, which has substituted that of the State, has not succeeded in redressing the effects of the absence of State intervention because it does not solve the problem of different levels of services in different areas of the country.

The relationship between the State and the Regions has often been riddled with constitutional conflicts. The division of competences between State and Regions and the complex financing system under the Italian legal order could

58 Judgements no. 306 of 2008; no. 187 of 2010; no. 269 of 2010; no. 40 of 2011; no. 61 of 2011.

59 On this issue see Gabriella Saputelli, "Differenziazioni regionali in merito all'accesso dei migranti ai servizi sociali," in I diritti di cittadinanza dei migranti, Il ruolo delle Regioni, ed. Laura Ronchetti (Milano: Giuffré, 2012), 227-263; Laura Ronchetti, "I diritti fondamentali alla prova delle migrazioni (a proposito delle sentenze nn. 299 del 2010 e 61 del 2011)," Rivista AIC, no. 3 (2011); on the rights of migrants see Enzo Di Salvatore and Michela Michetti, I diritti degli altri, Gli stranieri e le autorità di governo (Napoli: Esi, 2014). 
not avoid the intervention of the constitutional Court, which has the function of clarifying and defining a balance between the two legislators. In recent years, some elements have revealed that the system has been going from conflict to 'gentlemen's agreements' and to institutional involvement.

In 2012, when the national resources for the Regions were significantly reduced, there was no agreement in the State-Regions Conference (or the Joint Conference) on the allocation of Social Funds because of insufficient resources, and the distribution of funds was frozen. This circumstance was the starting point for moving into a phase of negotiations.

The following year, the Ministry of Labour and Social Policies 'transposed' the Nomenclature of Services and Social Measures adopted by the Conference of Regions and of Autonomous Provinces in 2009 into the administrative decree for the distribution of National Social Policies Fund for the period $2013-2015 .{ }^{60}$ Consequently, agreements were reached on allocations from the National Social Policy Fund and resources were distributed.

This mechanism was repeated in the following years. The recent Act on Minimum Income ${ }^{61}$ introduced a new form of regional participation: a network which involves a delegation from each regional or provincial Government is commissioned to develop a number of plans (the National Social Plan, the Social Action Plan and Social Services for Poverty, the Plan for Self-Sufficiency) and to define guidelines for social policies. It is worth specifying that this novelty does not exclude, but it comes to add to, the participation in the Joint Conference because it precedes the legislative phase.

In the decentralised Italian system, the Regions have become essential interlocutors of the State which, in defining its policies, cannot ignore the results achieved. Both the nomenclature of 2009 and the network introduced in the recent Legislative Decree confirm this relationship.

The real challenge for the State and the Regions seems to be the need to find a 'no-conflict zone' for participation wherein policies can be defined. This question involves the well-known problems of the lack of an institutional forum where the Regions can participate in the legislative process (which is a characteristic of Federal States). ${ }^{62}$ As mentioned in this chapter on the Italian

6o DM 26/6/2013.

61 L. 15 marzo 2017, n. 33, Delega recante norme relative al contrasto della poverta', al riordino delle prestazioni e al sistema degli interventi e dei servizi sociali. (17Gooo47) (GU Serie Generale n.7o del 24-03-2017) available on https://www.gazzettaufficiale.it/eli/id/2017/ $03 / 24 / 17 \mathrm{Gooo} 47 / \mathrm{sg}$.

62 On the second Chamber there is a vast literature. See Stelio Mangiameli, ed., Un senato delle autonomie per l'Italia federale (Napoli: Edizioni Scientifiche Italiane, 2003); Luca Castelli, Il Senato delle autonomie, Ragioni, modelli, vicende (Padova: Cedam, 2010); 
experience, the system of Conferences, even if considered inadequate, is used 'in the continuing absence of changes in the parliamentary institutions'. ${ }^{63}$ While the choice of cooperation compensates for the absence of a 'Senate of the Regions', the issue of financial regional autonomy remains unsolved.

Failure to implement Article 119 of the Constitution (financial autonomy), together with the State competence over coordination of public finance have been obstacles to the autonomous management of regional policies. ${ }^{64}$ Without fiscal powers and being repeatedly subject to linear cuts, the Regions are unable to achieve the purpose of being the institution that can best meet the needs of the territories. As is well known, these two elements are essential in a regional state, and their absence undermines the functioning of the system.

It can be concluded that the analysis of the institutional political events and the case law of the Court shows that the implementation of the principle of equality in the Italian regional system was not achieved through a dual system of rigid separation of competences, but through an often contradictory dynamic process of relations between central and regional levels.

Furthermore, in a decentralised system, the two principles of autonomy and equality may seem to be in opposition with each other, but an analysis of social care in the Italian system has shown that the principle of equality can also be achieved through autonomy. This circumstance demonstrates the value of the decentralised system, where the two levels stimulate each other - even through conflict - and play a mutually complementary role. Indeed, the Regions which are the institutions that are closest to the citizens are responsible for the needs and demands that come from the communities and can develop diverse experiences in the territory. Obviously, there is a tension between the two institutional subjects (State and Regions), but this tension is functional to the implementation of equality.

D’Atena, Tra autonomia e neocentralismo, 271 et seq; Eduardo Gianfrancesco, "La partecipazione delle regioni alla vita dello Stato (e della Repubblica): bicameralismo, camera delle regioni e conferenze," Italian Papers on Federalism, no. 2 (2017).

63 Judgement no. 6 of 2004. On the system of Conferences see Guido Carpani, La Conferenza Stato-regioni, Competenze e modalità di funzionamento dall'istituzione ad oggi (Bologna: Il Mulino, 2006), 2o; Riccardo Carpino, "Evoluzione del sistema delle Conferenze," Istituzioni del Federalismo, no. 1 (20o6): 19 et seq; Commissione parlamentare per le questioni regionali, A Conclusione dell'indagine conoscitiva sulle forme di raccordo tra lo Stato e le Autonomie territoriali, con particolare riguardo al 'Sistema delle Conferenze' - Approvato dalla Commissione parlamentare per le questioni regionali nella seduta del 13 ottobre 2016, Doc. XVII-bis n. 7, http://www.senato.it/service/PDF/PDFServer/DF/327040.pdf.

64 See Antonio D'Atena, "The Financial Autonomy of Italy's Regional Authorities: its Constitutional Model and the History of its Implementation," Italian Papers on Federalism, no. 1 (2018): 1 . 
In this perspective, we can make use of what US Supreme Court Justice Louis Brandeis said in a famous Dissenting opinion:

Denial of the right to experiment may be fraught with serious consequences to the nation. It is one of the happy incidents of the federal system that a single courageous State may, if its citizens choose, serve as a laboratory; and try novel social and economic experiments without risk to the rest of the country. This Court has the power to prevent an experiment. We may strike down the statute which embodies it on the ground that, in our opinion, the measure is arbitrary, capricious, or unreasonable. We have the power to do this because the due process clause has been held by the Court applicable to matters of substantive law as well as to matters of procedure. But, in the exercise of this high power, we must be ever on our guard lest we erect our prejudices into legal principles. If we would guide by the light of reason, we must let our minds be bold. 65

\section{Bibliography}

AaVv., Corte costituzionale e principio di eguaglianza, Atti del Convegno in ricordo di Livio Paladin. Padova: Cedam, 2002.

Agrò, Antonio Stefano. "Art. 3." In Commentario della Costituzione, edited by Giuseppe Branca, 123 et seq. Bologna, Roma: Zanichelli, 1975.

Antonini, Luca. "La vicenda e la prospettiva dell'autonomia finanziaria regionale: dal vecchio al nuovo art. 119." Le Regioni 1 (2003): 11-40.

Anzon Demmig, Adele. "Potestà legislativa regionale residuale e livelli essenziali delle prestazioni."Giurisprudenza Costituzionale, no. 1 (2010): 155 et seq.

Gianolio, Roberto, Luciano Guerzoni and G. Paolo Storchi, eds. Assistenza e beneficenza tra pubblico e privato. Milano: Franco Angeli, 1980.

Balboni, Enzo. "Il concetto di 'livelli essenziali e uniformi' come garanzia in materia di diritti sociali." Le istituzioni del federalismo, no 6 (2001): 1103-1111.

Balboni, Enzo, Bassano Baroni and Angelo Mattioni, eds. Il sistema integrato dei servizi sociali, Commento alla legge no. 328 of 2000 e ai provvedimenti attuativi dopo la riforma del titolo V della Costituzione. Milano: Giuffré, 2003.

65 Luis Brandeis, Dissenting opinion, in US Supreme Court, New State Ice Co. v. Liebmann (1932, no. 463), 285 U.S. 262, Judgement of 21 March 1932. 
Balboni, Enzo. "Coesione sociale e livelli essenziali delle prestazioni: due paradigmi paralleli della tutela multilivello dei diritti sociali." In La tutela multilivello dei diritti sociali, edited by Enzo Balboni, 3-18. Napoli:Jovene, 2008.

Balboni, Enzo. "I livelli essenziali e i procedimenti per la loro determinazione." Le Regioni, no. 6 (2013): 1183-1199.

Banchero, Anna. "I livelli essenziali delle prestazioni nell'ambito dei servizi alla persona: dalla tutela della salute alla protezione sociale." Quaderni regionali, no. 2 (2008): 461-483.

Belletti, Michele. "I livelli essenziali delle prestazioni concernenti i diritti civili e sociali alla prova della giurisprudenza costituzionale, Alla ricerca del parametro plausibile." Le istituzioni del federalismo, no. 3-4 (2003): 613-646.

Belletti, Michele. "Forme di coordinamento della finanza pubblica e incidenza sulle competenze regionali, Il coordinamento per principi, di dettaglio e 'virtuoso', ovvero nuove declinazioni dell'unità economica e dell'unità giuridica." In Il regionalismo italiano tra giurisprudenza costituzionale e involuzioni legislative dopo la revisione del Titolo $V$ - Atti del Seminario, edited by Stelio Mangiameli, 86 et seq. Milano: Giuffré, 2014.

Biscaretti di Ruffia, Paolo. "Uguaglianza (principio di)." In Novissimo Digesto Italiano, $X I X$. Torino: Utet, 1973.

Bobbio, Norberto. Eguaglianza e libertà. Torino: Giappichelli, 1995.

Buglione, Enrico. "Regional Finance in Italy: Past and Future." In Italian Regionalism: Between Unitary Traditions and Federal Processes, Investigating Italy's Formof State, edited byStelio Mangiameli, 307-334. Heidelberg, Cham:Springer, 2014.

Caravita, Beniamino. Oltre l'eguaglianza formale, Un'analisi del'art. 3 comma 2 della Costituzione. Padova: Cedam, 1984.

Castelli, Luca. Il Senato delle autonomie, Ragioni, modelli, vicende. Padova: Cedam, 2010.

Carpani, Guido. La Conferenza Stato-regioni, Competenze e modalità di funzionamento dall'istituzione ad oggi. Bologna: Il Mulino, 2006.

Carpino, Riccardo. "Evoluzione del sistema delle Conferenze." Istituzioni del Federalismo, no. 1 (2006): 13-63.

Celotto, Alfonso. "Art. $3,1^{\circ}$ comma" In Commentario alla Costituzione, edited by Raffaele Bifulco, Alfonso Celotto and Marco Olivetti, 65 et seq. Milano: Utet giuridica, 2006.

Cerioni, Marta. "Un'ulteriore fattispecie di superamento giurisprudenziale della rigidità del riparto di competenze: 'I livelli essenziali delle prestazioni al tempo della crisi'." Giurisprudenza (2010): 2518-2524.

Cerri, Augusto. "Uguaglianza (principio costituzionale di)." In Enciclopedia Giuridica Treccani, XIV, edited by Pasquale Stanislao Mancini and Errico Pessina, 1-13. Milano: società editrice libraria, 2005 .

Colombo, Ugo M. Principi e ordinamento dell'assistenza sociale. Milano: Giuffré, 1959. 
Comino, Alberto, Alessandra De Marco and Alessandro Natalini. "La determinazione dei livelli essenziali delle prestazioni." In Welfare e federalismo, edited by Luisa Torchia, 95 et seq. Bologna: Il Mulino, 2005.

Corso, Guido. "I diritti sociali nella Costituzione italiana." Rivista Trimestrale di Diritto Pubblico (1981): 755 et seq.

D’Atena, Antonio. Tra autonomia e neocentralismo, Verso una nuova stagione del regionalismo italiano?. Torino: Giappichelli, 2016.

D’Atena, Antonio. Diritto regionale. Torino: Giappichelli, 2017.

D’Atena, Antonio. "Regionalism in Italy." Italian Papers on Federalism, no. 1 (2013).

D’Atena, Antonio. "The Financial Autonomy of Italy's Regional Authorities: its Constitutional Model and the History of its Implementation." Italian Papers on Federalism, no. 1(2018).

De Grazia, Davide. "L'autonomia finanziaria degli enti territoriali nel nuovo Titolo V della Costituzione." Le istituzioni del federalismo, no.2 (2002): 267-304.

Di Salvatore, Enzo and Michela Michetti. I diritti degli altri, Gli stranieri e le autorità di governo. Napoli: Esi, 2014.

Esposito, Carlo. “Eguaglianza e giustizia nell'art. 3 della Costituzione.” In La Costituzione italiana, Saggi, edited by Carlo Esposito, 17 et seq. Padova: Cedam, 1954.

Ferioli, Elena. Diritti e servizi sociali nel passaggio dal welfare statale al welfare municipale. Torino: Giappichelli, 2003.

France, George. "The Italian Health Care System and the Economics of the Right to Health." In Italian Regionalism: Between Unitary Traditions and Federal Processes, edited by Stelio Mangiameli, 335-352. Heidelberg, Cham: Springer, 2014.

Giarda, Piero. "Le regole del federalismo fiscale nell'articolo 119: un'economista di fronte alla nuova Costituzione." Le Regioni, no. 6 (2001): 1425-1484.

Giorgis, Andrea. "Art. $3,2^{\circ}$ comma" In Commentario alla Costituzione, edited by Raffaele Bifulco, Alfonso Celotto and Marco Olivetti, 88 et seq. Milano; Utet giuridica, 2006.

Gianfrancesco, Eduardo. "La partecipazione delle regioni alla vita dello Stato (e della Repubblica): bicameralismo, camera delle regioni e conferenze.” Italian Papers on Federalism, no. 2 (2017). http://italianpapersonfederalism.issirfa.cnr.it/lapartecipazione-delle-regioni-alla-vita-dello-stato-e-della-repubblica-bicameralismo -camera-delle-regioni-e-conferenze.html.

Gori, Cristiano. "I livelli essenziali di assistenza." In La riforma dei servizi sociali in Italia, L'attuazione della legge 328 e le sfide future, edited by Cristiano Gori, 55 et seq. Roma: Carocci, 2002.

Gori, Cristiano. "Applicare i livelli essenziali nel sociale." Prospettive sociali e sanitarie 33, no. 15 (2003): 1-8.

Gori, Cristiano, Valentina Ghetti, Giselda Rusmini and Rosemarie Tidoli. Il welfare sociale in Italia, Realtà e prospettive. Roma: Carocci, 2015. 
Gori, Cristiano and Ilaria Madama. "Le politiche socio-assistenziali." In La riforma del Welfare, Dieci anni dopo la 'Commissione Onofri', ed. Luciano Gurzoni, 347-358. Bologna: Il Mulino, 2007.

Guiglia, Giovanni. I livelli essenziali delle prestazioni sociali alla luce della recente giurisprudenza costituzionale e dell'evoluzione interpretativa. Padova: Cedam, 2007.

Kazepov, Yuri, ed. La dimensione territoriale delle politiche sociali in Italia. Roma: Carocci, 2014.

Longo, Erik. "I diritti sociali al tempo della crisi, La Consulta salva la social card e ne ricava un nuovo titolo di competenza statale." Giurisprudenza costituzionale 55 (2010): 164-184.

Madama, Ilaria. Le politiche di assistenza sociale. Bologna: Il Mulino, 2010.

Maggian, Raffaello. Il sistema integrato dell'assistenza. Roma: Carocci, 2003.

Mangiameli, Stelio. La riforma del regionalismo italiano. Torino: Giappichelli, 2002.

Mangiameli, Stelio, ed. Un senato delle autonomie per l'Italia federale. Napoli: Edizioni Scientifiche Italiane, 2003 .

Mangiameli, Stelio. "Autonomia finanziaria." In Dizionario sistematico di Diritto costituzionale, edited by Stelio Mangiameli, 953-962. Milano: Il sole 24 Ore, 2008.

Mangiameli, Stelio. Le Regioni italiane tra crisi globale e neocentralismo. Milano: Giuffré, 2013.

Mangiameli, Stelio. "Il Titolo V della Costituzione alla luce della giurisprudenza costituzionale e delle prospettive di riforma." Rivista AIC, no. 2 (2016). https://www. rivistaaic.it/it/rivista/ultimi-contributi-pubblicati/stelio-mangiameli/il-titolo-vdella-costituzione-alla-luce-della-giurisprudenza-costituzionale-e-delle-prospettive-di-riforma.

Mangiameli, Stelio. Italian Regionalism: Between Unitary Traditions and Federal Processes Investigating Italy's Form of State. Heidelberg, Cham: Springer, 2014.

Napolitano, Giulia Maria. "Social Care as a Workshop for Regional Welfare Policies." In Italian Regionalism: Between Unitary Traditions and Federal Processes, edited by Stelio Mangiameli, 36o-362. Heidelberg, Cham: Springer, 2014.

Napolitano, Giulia Maria. "Tendenze e problemi della legislazione regionale." In Rapporto sulla legislazione tra Stato, Regioni e Unione europea (Camera dei deputati), edited by Camera dei deputi. Rome: Camera dei deputi, 2007-2015. http://www. issirfa.cnr.it/rapporto-camera.html.

Paladin, Livio. Il principio costituzionale di eguaglianza. Milano: Giuffré, 1965.

Panzera, Claudio. "I livelli essenziali delle prestazioni concernenti i diritti sociali." In Diritto costituzionale e diritto amministrativo: un confronto giurisprudenziale, edited by Giuseppe Campanelli, Michele Carducci, Nicola Grasso, Vincenzo Tondi della Mura, 57-105. Torino: Giappichelli, 2010.

Panzera, Claudio. "I livelli essenziali delle prestazioni fra sussidiarietà e collaborazione." Le Regioni, no. 4 (2010): 938-957. 
Persiani, Mattia. "Art. 38." In Commentario della Costituzione, edited by Giuseppe Branca, 232 et seq. Bologna, Roma: Zanichelli, 1979.

Pizzorusso, Alessandro. Che cos'è l'eguaglianza. Roma: Editori riuniti, 1983.

Ronchetti, Laura. "I diritti fondamentali alla prova delle migrazioni (a proposito delle sentenze nn. 299 del 2010 e 61 del 2011)." Rivista AIC, no. 3 (2011). https://www.rivistaaic.it/it/rivista/ultimi-contributi-pubblicati/laura-ronchetti/i-diritti-fondamentali-alla-prova-delle-migrazioni-a-proposito-delle-sentenze-nn-299-del-2010e-61-del-2o11.

Ronchetti, Laura, ed. I diritti di cittadinanza dei migranti, Il ruolo delle Regioni. Milano: Giuffré, 2012.

Ronchetti, Laura, ed. La Repubblica e le migrazioni. Milano: Giuffré, 2014.

Rivosecchi, Guido. "Il coordinamento della finanza pubblica: dall'attuazione del titolo V alla deroga al riparto costituzionale delle competenze." In Il regionalismo italiano tra giurisprudenza costituzionale e involuzioni legislative dopo la revisione del Titolo $V$-Atti del Seminario, edited by Stelio Mangiameli, 147 et seq. Milano: Giuffré, 2014.

Rossano, Claudio. Il principio d'eguaglianza nell'ordinamento costituzionale. Milano: Giuffré, 1966.

Ruggeri, Antonio. “'Livelli essenziali' delle prestazioni relative ai diritti e ridefinizione delle sfere di competenza di Stato e Regioni in situazioni di emergenza economica (a prima lettura di Corte cost. n. 10 del 2010)." forumcostituzionale.it (February 2010). http://www.forumcostituzionale.it/wordpress/images/stories/pdf/documenti forum/giurisprudenza/2010/ooo2_nota_10_2010_ruggeri.pdf.

Saputelli, Gabriella. "Differenziazioni regionali in merito all'accesso dei migranti ai servizi sociali." In I diritti di cittadinanza dei migranti, Il ruolo delle Regioni, edited by Laura Ronchetti, 227-263. Milano: Giuffré, 2012.

Torchia, Luisa. "Premessa." In Welfare e federalismo, edited by Luisa Torchia, 15 et seq. Bologna: Il Mulino, 2005.

Trucco, Lara. "Livelli essenziali delle prestazioni e sostenibilità finanziaria dei diritti sociali." Gruppo di Pisa, Rivista, no. 3 (2012): 1-92. https://www.gruppodipisa.it/ images/rivista/pdf/Lara_Trucco_-_Livelli_essenziali_delle_prestazioni_e_sostenibilita_finanziaria_dei_diritti_sociali.pdf.

Violini, Lorenza. “Art. 38." In Commentario alla Costituzione, edited by Raffaele Bifulco, Alfonso Celotto and Marco Olivetti, 775 et seq. Milano: Utet giuridica, 2006. 